\title{
A KÖZKÖNYVTÁRAK MINT DEMOKRATIKUS TEREK
}

\section{RAGNAR AUDUNSON}

\section{Tartalmi összefoglaló}

A tanulmány elsősorban a könyvtárak megváltozott szerepét és lehetöségeit vizsgálja a 21. század kihivásai közepette. Megállapitást nyer, hogy a digitális globalizálódott világ újra életre hívja a közkönyvtárak egyik küldetését - mégpedig azt, hogy segitöen közremüködjenek abban, amit a demokratikus köztér biztositásának nevezünk. Ezeknek a fenntartható demokratikus tereknek adnak helyet a mai kor könyvtárai, és müködtetésükkel a könyvtárak társadalmi szerepe nem hogy nem csökken, hanem létfontosságúvá válik. A tanulmány egy pontján érdekes megállapítást veszát egy szakirodalomból, miszerint nem létezik olyan, hogy digitális bennszülött.

https://doi.org/10.46280/KOMPKONF.2020.Audunson

\section{A közkönyvtárak új és újraértelmezett küldetése?}

Michael H. Harris amerikai könyvtártörténész (1978) az 1922-ben működő amerikai közkönyvtárakat cél nélküli, de önmagukat fenntartó bürokratikus gépezetekként írta le. ${ }^{1}$ A demokráciát ért fenyegetések, a sztálinizmus és a nácizmus új célt adtak a könyvtáraknak; a demokrácia partizánjai lettek, mivel a polgároknak hozzáférést nyújtottak a politikai konfliktusok minden oldalához, nézőponthoz és szemponthoz, ezzel előmozdítva azt, hogy a polgárok tájékozottak legyenek, és képesek legyenek ellenállni az egyoldalú propagandának.

Hasonló helyzetben vagyunk-e napjainkban? Létfontosságúakká válnak-e a könyvtárak, amelyek fenntartható demokratikus tereket működtetnek a mai digitális és globalizálódott világban? Sok jel mutat ebbe az irányba. Egyidejűleg azzal, ahogy a digitalizálás lejjebb viszi a nyilvános önkifejezés küszöbét, és a globalizáció előmozdítja a kulturális kifejezés és impulzusok potenciálisan gyümölcsöző pluralizmusát, a nyilvános domén olyan kihívásokkal szembesül, amelyek a fragmentáció és a visszhangkamrák szavakkal összegezhetők - ezek olyan kihívások, amelyek összeomlással fenyegetik a közszférát. E tanulmányban arról írok, hogyan hívja mindez újra életre a közkönyvtárak egyik küldetését - mégpedig azt, hogy segítően közreműködjenek abban, amit a demokratikus köztér biztosításának nevezhetünk.

Úgy tűnik, politikai környezetünk tisztában van ezzel. Nemrégiben Norvégiában, Svédországban és Finnországban is módosították a (köz)könyvtári törvényt: Norvégiában

\footnotetext{
HARRIS, Michael H. - DAVIS, Donald G.: American library history. A bibliography. Austin, Tex., London, University of Texas Press, 1978. XIX, 260 p.
} 
és Svédországban 2014-ben, Finnországban 2016-ban. A könyvtárak független találkozóhelyként és a társadalmi diskurzus színtereként, a független közvélemény alakítását előmozdító intézményekként vannak definiálva, amelyek hozzáférést biztosítanak a tudáshoz (Svédország), és elősegítik a polgárok részvételét (Finnország), olyan elemek, melyek mindhárom törvény küldetésnyilatkozatában szerepelnek.

\section{Mi a könyvtárosság?}

Először is azonban tisztázni kell egy alapvető fogalmat, a könyvtárosság fogalmát. Mi a könyvtárosság? Sokak számára ez manapság kétséges fogalom. Szükségünk van-e a könyvtárosokra és a könyvtárakra ma, amikor közvetlen hozzáférésünk van a tudás forrásaihoz és a kulturális tapasztalatokhoz az internet közvetítésével?² A könyvtárosok igen sokféle összefüggés közepette dolgoznak. Mi köt össze egy gyerekrészlegben dolgozó könyvtárost, aki gyerekeket ösztönöz olvasásra, és például egy olyan könyvtárost, aki tapasztalt kutatók számára szolgáltat információt a nukleáris kémia területén? Van-e elegendő közös szakmai vonás tevékenységükben, hogy ugyanabba a szakmába, a könyvtárosságba tartozónak tekintsük őket?

Az első érvre a válasz - hogy tudniillik a könyvtárosokra már nincs szükség közvetítőként egy olyan világban, ahol az információ mindenütt jelen van az interneten, nem kötődik olyan intézményhez, mint a könyvtár, és elérhető a számítógépek révén: az a tény egy metaforát használva -, hogy a világ könyvtárrá lett, nem jelenti azt, hogy ne lenne szükségünk szakértő iránymutatásra ahhoz, hogy eligazodjunk az információ és a tudás világában. Ahogy a megboldogult Jon Bing professzor, a jogi informatika úttörője mondta önkénteseknek az IFLA 2005. évi konferenciáján Oslóban: „Ha azt hisszük, nincs szüusség könyvtárosokra, mivel az információ mindenütt körülvesz bennünket, az olyan, mint amikor azt hisszük, hogy nincs szükség autótérképre, mivel olyan sok az út körülöttünk." A digitális bennszülöttek mítosza, vagyis az a hiedelem, hogy akik 1990 után születtek, sajátos és velük született kompetenciákkal rendelkeznek, hogy eligazodjanak a digitális világban, az a kutatások szerint egy mítosz. ${ }^{3} \mathrm{Az}$ információs világ felszínének felületes vizsgálata valószínűleg lehetséges oktatás és iránymutatás nélkül is, de hogy teljességgel kihasználja valaki, annak az a feltétele, hogy szakemberek, például könyvtárosok segítsenek neki ebben. De az a tény, hogy az információ és a tudás mindenütt jelen van, és nem szükségszerűen kötődik intézményekhez - például könyvtárakhoz -, feltétlenül szükségessé teszi, hogy a könyvtárosság szakmailag újra orientálja magát. Már a könyvtárosság sem kötődik a könyvtárhoz, és nem határozza meg kizárólag a könyvtár fizikai intézményként, amely a fizikai gyüjtemény igényei szerint van rendezve. Tehát az eszköz, vagyis a gyüjtemény igényei helyett a könyvtárosok a küldetésükre koncentrálhatnak. És mi az a küldetés, ami közös a gyermekkönyvtáros

2 OLSEN, Kai A.: Trenger vi universitetsbiblioteket? = Aftenposten, 12. Aug. 2012. Forrás: https://www. aftenposten.no/ meninger/i/oEp6V/Trenger-vi-Universitetsbiblioteket [2018. október 31.]

3 KIRSCHNER, P. A. - DE BRUYCKERE, P.: The myths of the digital native and the multitasker. = Teaching and Teacher Education, 67, 2017. 135-142. p. Forrás: https://doi.org/10.1016/j.tate.2017.06.001 [2018. október 31.] 
és a nukleáris vegyészet tapasztalt kutatóját kiszolgáló könyvtáros között? A könyvtárosság generikus definíciójára a következőt javaslom: A könyvtárosok olyan szakemberek, akik a tudás és kultúra szervezett digitális és/vagy fizikai gyüjteménye alapján előmozdítják a tanulással, tudásmegosztással és kulturális tapasztalatokkal kapcsolatos társadalmi folyamatokat.

Ebben a meghatározásban a gyüjtemény az eszközt, míg a társadalmi folyamatok a küldetést képviselik. A digitalizálás felszabadítja a könyvtárosságot. A könyvtárak társadalmi küldetésükre összpontosíthatnak, nem pedig (mint korábban) az eszközök igényeire. Uralnunk kell azonban az eszközöket ahhoz, hogy sikeresen és hatékonyan tudjuk használni őket annak érdekében, hogy olyan társadalmi folyamatokat kezdeményezzünk, amelyek a könyvtárosság értelmét adják. Ezt a fontos szempontot hangsúlyoznunk kell ebben a korszakban, amikor - legalábbis a skandináv országokban - a könyvtár találkozóhelyként és demokratikus térként való fokozott hangsúlyozása más kompetenciákat feltételez, mint a könyvtárosi. A könyvtár nem csak egyfajta találkozóhely: az ott folyó tevékenység más, mint ami a többi találkozóhelyen (pl. kávézókban, közparkokban, sportlétesítményekben stb.) folyik: a középpontban a gyüjtemény tartalma áll.

\section{A könyvtárak mint demokratikus terek}

Amikor a levéltárakról és könyvtárakról mint közterekről beszélünk, elméleti megközelítésként legtöbbször talán Jürgen Habermas ${ }^{4}$ kulcsfontosságú, társadalmi nyilvánosságról szóló munkáit említjük. ${ }^{5} \mathrm{Ez}$ a cikk is erre a megközelítésre épül. A társadalmi nyilvánosságot a következőképpen definiálhatjuk:

1. A társadalmi nyilvánosság az állam, a piac és a privát szféra között helyezkedik el, és azoktól független. Ebben az állampolgárok azért találkoznak, hogy megvitassák a közös érdeklődésre számot tartó kérdéseket, amelyekben egyfajta közös véleményt lehet kialakítani.

2. Elvben nyitott bárki számára, és az emberek, akik ott találkoznak, egyenlő jogokkal rendelkeznek.

3. Kommunikációra és párbeszédre ad lehetőséget a vezetők és vezetettek között, ahol a kormányzati politikát kritizálni és alaposan elemezni lehet, és amely azt is biztosítja, hogy a kialakított közvélekedést el lehessen juttatni a hatóságokhoz.

4. A racionalitás normái uralkodnak. A résztvevők elkötelezettek a jobb érvek értéke iránt.

A könyvtárak általában, és a közkönyvtárak különösen olyan intézmények voltak a múltban és olyanok ma is, amelyek a társadalmi nyilvánosságot erősítik, mégpedig azáltal, hogy

4 magyarul: HABERMAS, Jürgen: A társadalmi nyilvánosság szerkezetváltozása. Ford. Endreffy Zoltán; Glavina Zsuzsa. Budapest, Gondolat, 1993. 395 p. (Századvég könyvtár)

5 BUSCHMAN, John E.: Dismantling the public sphere. Situating and sustaining librarianship in the age of the new public philosophy. Wesport, Libraries Unlimited, 2003. 232 p. (Contributions in librarianship and information science); WIDDERSHEIM, M. - KOIZUMI, M.: Conceptual modelling of the public sphere in public libraries. = Journal of Documentation, 73. 3. 2016. 591-610. p. Forrás: https://doi.org/10.1108/JD-06-2015-0079 [2018. október 31.] 
- lévén a felvilágosodás képviselői, előmozdítják a tájékozott és felvilágosult közösségi diskurzust,

- hozzáférést biztosítanak a tudáshoz és információhoz, amely a tájékozott és felvilágosult közösségi diskurzus feltétele,

- a közösségi viták színterei.

Ez nem új szerep, a modern közkönyvtár megszületése óta megvan, de a digitalizálás és a globalizáció olyan kihívásokat hoz létre, amelyek új és újra értelmezett fontosságot adnak ennek a szerepnek.

Bár tanulmányom a könyvtárak szerepét kiindulásképpen olyan intézményekként tárgyalja, amelyek alátámasztják a fenntartható társadalmi nyilvánosságot, de elismeri, hogy az a perspektíva, amely a társadalmi nyilvánosság elméletére és a racionális diskurzusra korlátozódik, túl szűk ahhoz, hogy a könyvtárakat, levéltárakat, múzeumokat mint demokratikus közösségi tereket megragadja. A társadalmi nyilvánosság-központú megközelítést ki kell egészíteni.

A könyvtárak, levéltárak és múzeumok lehetnek közterek vagy már eleve azok is, realizálva a tudást vagy a kulturális alkotásokat tartalmazó mütárgyak közkincs-potenciálját, mely mütárgyak nélkülük magánkézben lennének. Ezáltal a könyvtárak, levéltárak és múzeumok demokratikus hozzáférést adnak a tudáshoz és a kulturális alkotásokhoz. A használók viselkedése általában véve állampolgári szerepükkel vagy egyéni és magán jellegű igényeikkel és érdeklődésükkel hozható összefüggésbe, és nem sok köze lehet a társadalmi nyilvánossághoz.

A könyvtárak, levéltárak és múzeumok lehetnek demokratikus terek, vagy azok is, mivel a közösség olyan terei, ${ }^{6}$ ahol idegenekkel vagy olyan emberekkel lehet találkozni, akiket csak felületesen ismerünk, és ahol az idegenek közti viselkedést strukturáló normák szolgálnak támpontul a viselkedéshez. Ily módon a látogatók szembesülnek a mai társadalom komplexitásával, melyet remélhetőleg megtanulnak elfogadni. ${ }^{7}$ A könyvtárak alacsony intenzitású találkozóhelyekként használóikat olyan normákkal és értékekkel ismertetik meg, melyek eltérőek a megszokottól, az általuk elfogadottól. A közgyüjtemények szembesítenek bennünket a társadalom pluralizmusával és komplexitásával, és olyan demokratikus változásokat idéznek elő, amelyek ellensúlyozzák a fragmentáció és a visszhangkamrák irányába mutató fejleményeket.

Ugyanakkor, a közgyüjtemények lehetnek olyan harmadik helyek is, „, ahol mindenki is-

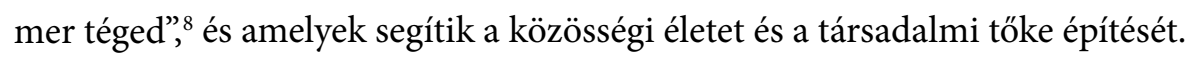

6 SENNETT, R. (2009). The public realm. In: BRIDGE, G. - WATSON, S. (eds): The Blackwell city reader. Chichester, WileyBlackwell, 2009. 261-272. p.

7 STRAUSS, A.: Spatial representation of the orbits of city life. = Sociological Quarterly, 1. 3. 1960. 167-180. p. Forrás: https://doi.org/10.1111/j.1533-8525.1960.tb01470.x [2018. október 31.]

8 JOHNSTON, C. A. - GRIFFIS, M. R.: A place where everybody knows your name. Investigating the relationship between public libraries and social capital. $=$ Canadian Journal of Information and Library Science, 33. 2009. 159-191. p. 
A könyvtáraknak mint demokratikus köztereknek a különböző dimenziói mind szükségesek, hogy megértsük a könyvtárak ezen szerepét.

A következőkben általában véve a fenntartható demokratikus közterekkel kapcsolatos néhány kihívást és különösen a fenntartható és funkcionáló társadalmi nyilvánosság kihívásait vitatjuk meg, továbbá azokat a következményeket is, melyeket e kihívások tartogatnak a közkönyvtárak számára.

\section{Első kihívás - A hagyományos hordozók válsága}

A hagyományos hordozók - előbb a nyomtatott hírlapok, folyóiratok és könyvek, majd a rádió és a televízió - létfontosságúak voltak a társadalmi nyilvánosság létrehozásában és fenntartásában. Olyan csatornák voltak, amelyeket a kormányzatok arra használtak, hogy közöljék politikájukat a nagyközönséggel, és ugyanakkor a színterei voltak annak is, hogy a nagyközönség kritizálja és alaposan elemezze ezeket a politikákat, és közölje a kritikát a hatósággal. A tömegkommunikációban a hatalmon lévők arra vannak kényszerítve, hogy a tartalomért és döntéseik következményeiért felelösséget vállaljanak a nagyközönség előtt. Az emberek többségét elérő tömegkommunikációs eszközök másik fontos hatása, hogy közös tematikát tartanak fenn, amely a közös nyilvános diskurzus fenntartásának másik lényeges elöfeltétele.

A digitalizálás a hagyományos tömegkommunikációs eszközök válságához vezetett. A norvégiai fejleményeket példaként véve: míg 1991-ben a felnőtt norvégok 84\%-a olvasott naponta nyomtatott hírlapot, 2000-ben ez a szám 77\%-ra csökkent. 2016-ban már csak a felnőtt lakosság 39\%-a olvasott, és az olvasói hajlandóság drámai csökkenése folytatódik: 2017-ben már csak 32\% volt, aki ténylegesen kézbe vette a nyomtatott sajtót. Bár az internetes lapok olvasása bizonyos fokig kárpótolhatja az olvasókat, a bármilyen hordozón megjelenő hírlapok olvasása 2017-ben összesen 68\%-os volt a 2016-os 73\% helyett, ami lényegesen kevesebb az1990-es, az internet előtti adatoknál (84\%). Más az interneten újságot olvasni, mint nyomtatásban. Az interneten olvasók figyelme könnyen eltéríthetö, követik a linkeket és legördítik a híreket, kismértékben olvasnak elmélyülten. Thurman és Fletcher (2018) esettanulmányt készített azt követően, hogy egy vezető brit lap, a The Independent 2016-ban áttért a kizárólag digitális kiadásra. ${ }^{9}$ Bár a teljes brit olvasóközönségre ez nem volt jelentős hatással, a The Independent brit olvasói által olvasásra fordított idő 81\%-kal csökkent, ami azt jelzi, hogy az olvasás felületesebb.

Kompenzálhatják-e a könyvtárak a társadalmi nyilvánosság platformjaiként a hagyományos média gyengülését? Egy svéd tanulmány azt írta, „hogy a közkönyvtáraknak kötelességük és egyben lehetöségük is, hogy szembeszálljanak azokkal a tendenciákkal, amelyeket a közigazgatás csekély mértékü megjelenitése, a társadalmak és a dokumentumok töredezettsége és a felelösségnek a kormányzati szervekröl a könyvtárakra való átruházása jellemez. Ha megfelelöen

9 THURMAN, N. - FLETCHER, R.: Are newspapers heading toward post-print obscurity? A case study of The Independent's transition to online. = Digital Journalism, 6. 8. 2018. Forrás: https://doi.org/10.1080/21670811.2018.1504625 [2018. október 31.] 
kezelik a könyvtárak értéknövelö gyakorlatát, megerösithetik és felfrissithetik a demokratikus rendszert."10 A könyvtárosoknak komolyan kell venniük ezt a kihívást, és ki kell próbálniuk lehetőségeiket a társadalmi nyilvánosság támogatására a településeken, ahol a helyi polgárok összejöhetnek, és valós időben, generációs, társadalmi és kulturális különbségeket félretéve megvitathatják közös dolgaikat.

\section{Második kihívás - A tudáshoz való hozzáférés - a poszt- faktuális társadalom}

A neten elérhető hatalmas mennyiségü információ kritikus értékelésének, az álhíreknek és álkommenteknek a valódiaktól való megkülönböztetésének a képessége sokkal fontosabb, mint valaha. Egy nemrég megjelent norvég tanulmány 666 tizenöt évesnél fiatalabb norvég fiatal navigációs készségeit és keresési stratégiáit vizsgálta. ${ }^{11}$ Tove Frønes azt tapasztalta, hogy a fiataloknak nincsenek megfelelő navigációs készségeik, és arra sem képesek, hogy kritikusan értékeljék a talált információt, tehát fennáll a veszély, hogy álhírek áldozataivá válnak. Frønes megállapításai aláhúzzák a fent kifejtetteket: nem létezik olyan, hogy digitális bennszülött, és ma minden eddiginél inkább szükség van a könyvtárosokra, akik rendelkeznek az ahhoz szükséges kompetenciákkal, hogy segítsenek a digitális információk világában navigálni, és ösztönözzék a digitális írástudás elterjedését. A tájékozott és felvilágosult közösségi diskurzushoz és a tájékozott döntések meghozatalára képes polgároknak arra van szüksége, hogy az információ minősége garantált legyen. A könyvtárosok egy létfontosságú szakmát képviselnek, amikor a jól működő társadalmi nyilvánosság elengedhetetlen feltételének a biztosításáról van szó.

\section{Harmadik kihívás - Állampolgári készségek}

A digitalizálással alacsonyabbá válik a véleményüket nyilvánosan kinyilvánítók részvételi küszöbe. A megnövekedett részvétel megnövekedett demokráciához vezethet, de ha ezekkel a lehetőségekkel élni szeretnénk, fejleszteni kell a polgárok állampolgári készségeit. Ha ezt a feltételt nem biztosítjuk, a nyilvános diskurzus összeomolhat a szitkozódások, szexizmus és zaklatások miatt. A közösségi médiában sok erre mutató jel figyelhető meg. A nyilvános diskurzus sok résztvevője (különösen a nők) arról számolnak be, hogy zaklatás érte őket. Ahogy a finn közkönyvtári törvényben olvasható, a könyvtárak egyik fontos célja az aktív polgári lét és polgári készségek előmozdítása. Ez az előfeltétele annak, hogy valóra váljanak a digitális forradalom pozitív demokratikus lehetőségei.

10 JOHANSSON, V.: Public libraries as democratic intermediaries. Some examples from Sweden. = New Library World, $105.1-2$. 2004. 47-59. p. Forrás: https://doi.org/10.1108/03074800410515264 [2018. október 31.]

11 FRØNES, Tove Stjern: Å lese og navigere på nettet. En studie av elevers navigasjonsstrategier. PhD-dissertation. Oslo, Oslo University, 2017. 


\section{Negyedik kihívás - Visszhangkamrák}

A digitalizálás lehetővé teszi számunkra, hogy kiépítsük saját információs univerzumunkat, ahol azokkal az érdekekkel és értékekkel találkozunk, amelyek nekünk kedvesek, és védve vagyunk azoktól az érdekektől és értékektől, melyeket nem szeretünk. Ezeket a lehetőségeket igyekszünk is kihasználni. Saját jegyzékbe vesszük kedvenc zeneszámainkat, a Facebookon olyan linkeket kapunk, amelyek megerősítik eddigi viselkedésünket és érdeklődésünket stb. Miért is hallgatnánk olyat, amit nem szeretünk, vagy olvasnánk olyan cikkeket, melyek olyasmivel foglalkoznak, amit nem kedvelünk, és pocsékolnánk az időket olyasmire, amihez nincs partnerünk? Egyre inkább információs és kulturális visszhangkamrákban éljük életünket. ${ }^{12} \mathrm{~A}$ demokráciának viszont az az előfeltétele, hogy ki vagyunk téve másféle értékeknek és érdekeknek és legitimnek kell elfogadnunk ezeket, pedig eltérnek a mieinktől. Trond Berg Eriksen norvég eszmetörténész szerint a hagyományos hírlapok és könyvtárak egyik fö hatása az, hogy az újságolvasóknak és a könyvtárhasználóknak meg kell barátkozniuk a világ érdekeinek és értékeinek pluralizmusával. ${ }^{13} \mathrm{~A}$ hagyományos hírlapok hanyatlása idején ennek a felelősségnek a súlya még inkább a könyvtárakra hárul, hogy ellensúlyozni tudják a visszhangkamrák tendenciáját azzal, hogy alacsony intenzitású találkozóhelyekként alakítják ki szerepkörüket, azaz olyan színtérekként, ahol a sajátunktól eltérő kifejezési módokkal, értékekkel és érdekekkel is találkozunk. ${ }^{14}$

\section{Ötödik kihívás - Eltünőben vannak azok a társadalmi mozgalmak, amelyek a helyi és a központi szint közötti kommunikációs csatornákat létrehozzák}

Tranvik és Selle megjegyzi, hogy a demokráciának fontos dimenzióját jelentik például a szakszervezetek, a laikusokat tömörítő vallási szervezetek és a kulturális mozgalmak. ${ }^{15}$ A 20. század folyamán ezek olyan szervezetekként alakultak ki, amelyeknek tömeges tagságuk és kiterjedt helyi szervezeteik voltak, központi szinten kapcsolatban álltak a kormányzati szintü döntéshozatali testületekkel. Ezek a szervezetek akkoriban olyan kommunikációs csatornák voltak, amelyek képesek voltak az alulról jövő, helyi közösségekből származó viselkedések és érdekek közvetítésére a regionális szinten át, fel a kormányzati szintig. Ezek a szervezetek tömeges és aktív tagsággal rendelkező társadalmi mozgalmakként jelentős mértékben

12 SUNSTEIN, C.: Divided democracy in the age of social media. Princeton, Princeton University Press, 2018.

13 ERIKSEN, Trond Berg: Profesjonsetikk. = Bok og Bibliotek, 55. 6. 1988. 4-6. p.

14 AUDUNSON, Ragnar: The public library as a meeting place in a multicultural and digital context: the necessity of low intensive meeting places. = Journal of Documentation, 61. 2005. 429-441. p. Forrás: https://www.emeraldinsight.com/doi/ full/10.1108/00220410510598562 [2018. október 31.]

15 TRANVIK, T. - SELLE, P.: Farvel til folkestyret. Nasjonalstaten og de nye nettverkene. Oslo, Gyldendal Akademisk, 2003.; TRANVIK, T. - SELLE, P.: The rise and fall of popular mass movements. Organizational change and globalization - the Norwegian case. = Acta Sociologica, 2007. Forrás: https://doi.org/10.1177/0001699307074883 [2018. október31.] 
elsorvadtak, és átalakultak olyan szakértő személyzettel rendelkező regionális és központi szintű hivatalokká, amelyek csak lazán kötődnek az alulról jövő kezdeményezésekhez a települések szintjén, és tagságuk egyre csökken. A közkönyvtárak, amelyek erősen helyi kötődésűek, és a legtöbb településen közösségi helyszínnel rendelkeznek, olyan pozícióban lehetnek, hogy megszervezzék a helyi vitákat, és ugyanakkor közvetítsenek a helyi és az országos szint között, ezzel kompenzálva a társadalmi tömegszervezetek eltűnését.

\section{Következtetések}

A digitalizálás és a globalizáció a demokratikus tereket általában és a működő társadalmi nyilvánosságot különösképpen nyomás alá helyezi. A társadalmi nyilvánosság számára fö támaszt jelentő hagyományos hordozók válsága, a megbízható tudáshoz való hozzáférés az álhírek közepette, az állampolgári készségek hiánya, a töredezettség és a visszhangkamrák, továbbá a népszerü tömegszervezetek fokozatos eltűnése - ez mind-mind a társadalmi nyilvánosságot veszélyezteti. A könyvtárak (különösen a közkönyvtárak) e kihívásokat tekintve hasznosak lehetnek. Napjaink könyvtárügye számára nagyon fontos feladat, hogy megfelelö válaszokat adjon ezekre a kihívásokra.

\section{Irodalom}

AUDUNSON, Ragnar: The public library as a meeting place in a multicultural and digital context: the necessity of low intensive meeting places. $=$ Journal of Documentation, 61, 2005. 429-441. p.

Forrás: https://www.emeraldinsight.com/doi/full/10.1108/00220410510598562 [2018. október 31.]

BUSCHMAN, John E.: Dismantling the public sphere. Situating and sustaining librarianship in the age of the new public philosophy. Wesport, Libraries Unlimited, 2003. 232 p. (Contributions in librarianship and information science)

ERIKSEN, Trond Berg: Profesjonsetikk. = Bok og Bibliotek, 55. 6. 1988. 4-6. p.

FRØNES, Tove Stjern: Å lese og navigere på nettet. En studie av elevers navigasjonsstrategier. PhD-dissertation. Oslo, Oslo University, 2017.

HABERMAS, Jürgen: A társadalmi nyilvánosság szerkezetváltozása. Ford. Endreffy Zoltán; Glavina Zsuzsa. Budapest, Gondolat, 1993. 395 p. (Századvég könyvtár)

HARRIS, Michael H. - DAVIS, Donald G.: American library history. A bibliography. Austin, Tex., London, University of Texas Press, 1978. XIX, 260 p.

JOHANSSON, V.: Public Libraries as democratic intermediaries. Some examples from Sweden. = New Library World, 105. 1-2. 2004. 47-59. p. Forrás: https://doi.org/10.1108/03074800410515264 [2018. október 31.]

JOHNSTON, C. A. - GRIFFIS, M. R.: A place where everybody knows your name. Investigating the relationship between public libraries and social capital. = Canadian Journal of Information and Library Science, 33. 2009. 159 - 191. p.

KIRSCHNER, P. A. - DE BRUYCKERE, P.: The myths of the digital native and the multitasker. $=$ Teaching and Teacher Education, 67. 2017. 135-142. p. Forrás: https://doi.org/10.1016/j. tate.2017.06.001 [2018. október31.] 
NICHOLAS, D.: Disintermediated, decoupled and down. = CilipUpdate, 3. 2012. 29-31. p.

Forrás: http://ciber-research.eu/download/20120501-CILIP_Update_March_2012_pp29-31

[2018. október 31.]

OLSEN, K.A.: Trenger vi universitetsbiblioteket? = Aftenposten, 12. Aug. 2012.

SENNETT, R. (2009). The public realm. In: BRIDGE, G., WATSON, S. (eds): The Blackwell city reader. Chichester, Wiley-Blackwell. 2009. 261-272. p.

STATISTISK Sentralbyrå. Norsk kulturbarometer 2017. Oslo.

Forrás: https://www.ssb.no/kulturbar [2018. október 31.]

STRAUSS, A.: Spatial representation of the orbits of city life. = Sociological Quarterly, 1. 3. 1960.

167-180. p. Forrás: https://doi.org/10.1111/j.1533-8525.1960.tb01470.x [2018. október 31.]

SUNSTEIN, C.: Divided democracy in the age of social media. Princeton, Princeton University Press, 2018.

THURMAN, N. - FLETCHER, R.: Are newspapers heading toward post-print obscurity? A case study of The Independent's transition to only. = Digital Journalism, 6. 8. 2018. Forrás: https://doi.org/ 10.1080/21670811.2018.1504625 [2018. október 31.]

TRANVIK, T. - SELLE, P.: Farvel til folkestyret. Nasjonalstaten og de nye nettverkene. Oslo, Gyldendal Akademisk, 2003.

TRANVIK, T. - SELLE, P.: The rise and fall of popular mass movements. Organizational change and globalization - the Norwegian case. $=$ Acta Sociologica, 2007.

Forrás: https://doi.org/10.1177/0001699307074883 [2018. október 31.]

WIDDERSHEIM, M.: Late, lost or renewed? A search for the public sphere in public libraries. = InformationR.net, 2017. Forrás: http://www.informationr.net/ir/22/colis/colis1644.html [2018. október 31.]

WIDDERSHEIM, M. - KOIZUMI, M.: Conceptual modelling of the public sphere in public libraries. = Journal of Documentation, 73. 3. 2016. 591-610. p. Forrás: https://doi.org/10.1108/JD-06-2015-

0079 [2018. október 31.]

Ragnar Audunson a Metropolitan University (Oslo), korábban a Department of Archivistics, Library and Information Science és az Akershus University College professzora. 2002 és 2008 között a könyvtár- és információtudományi képzéssel és kutatással foglalkozó európai szervezet (EUCLID) elnöki teendőit látta el, és ugyanabban az időszakban az IFLA Könyvtári Elmélettel és Kutatással foglalkozó állandó bizottságának (SC Library Theory and Research) elnöke volt. 2007 és 2012 között a PLACE (Public Libraries - Arenas for Citizenship) projekt vezetője. Ezt a projektet a Norvég Kutatási Tanács (Norwegian Research Council) finanszírozta. Jelenleg az ALMPUB projekt vezetője, amely a közgyűjteményeket mint a nyilvánosság fenntartható intézményeinek infrastruktúráját vizsgálja. Ez a projekt 2016 és 2019 között folyik, és részt vesz benne az OSZK Könyvtári Intézete is. 